\title{
Public spaces and physical activity in adults: insights from a mixed-methods study
}

\section{Espacios públicos y actividad física en adultos: reflexiones de un estudio de métodos combinados}

\section{Espaços públicos e atividade física em adultos: um estudo de métodos mistos}

Ietza Bojorquez 1

Maria de Lourdes Romo-Aguilar 1

Lina Ojeda-Revah 1

Fernando Tena 1

Francisco Lara-Valencia 2

Hilda García 1

Rolando Díaz 3

Patricia Aranda 3

doi: 10.1590/0102-311X00028720

\begin{abstract}
Public spaces could promote health equity by providing a place for people to engage in physical activity. Whereas most studies show a positive association between public spaces and physical activity, there are still mixed results, especially in low-and middle-income countries. The objectives of this mixedmethods study were: (i) to assess the quantitative association between access to public spaces and physical activity; (ii) to assess the modification of the association by public spaces quality, area-level walkability, and social stratifiers; (iii) to explain the quantitative results using qualitative data. Quantitative data were obtained with a household survey in two arid-climate Mexican cities in 2017-2018. physical activity was measured with the Global Physical Activity Questionnaire. Access to public spaces was measured in buffers centered on survey blocks, walkability with area-level indicators, and public spaces quality with the Physical Activity Resources Assessment. Qualitative data were obtained with semi-structured interviews and neighborhood observation. No quantitative association between access to public spaces and physical activity was found, as well as no interactions between access to public spaces and other variables. Walkability was positively associated with physical activity. Qualitative analysis showed that local public spaces were rarely used by adults because they were perceived as small, unequipped, unattractive, and unsafe. The results shed light on the relationship between public spaces and physical activity, highlighting the improvements in design and upkeep of public spaces that are necessary to achieve their potential health benefit.
\end{abstract}

Correspondence

I. Bojorquez

El Colegio de la Frontera Norte.

Km 18,5 Carretera Escénica Tijuana-Ensenada, Tijuana, Baja California 22560, México.

ietzabojorquez@gmail.com

${ }^{1}$ El Colegio de la Frontera Norte, Tijuana, México.

2 Arizona State University, Tempe, U.S.A.

${ }_{3}^{3}$ El Colegio de Sonora, Hermosillo, México.

Motor Activity; Exercise; Built Environment; Recreational Parks 


\section{Introduction}

Insufficient physical activity is a major risk factor for death and disability, but more than $50 \%$ of adults are physically inactive worldwide 1 . The promotion of physical activities is important for public health, and public spaces could be significant for this, providing people with a place for engaging in physical activity, and a destination to walk to or through 2. Previous studies suggest that living close to parks, green areas, and other public spaces is associated with more physical activity 3,4 . However, there are still mixed results, and some researchers have reported lower physical activity levels among those living closer to public spaces 3,5,6,7.

These contrasting results might be explained by characteristics that modify the relationship between public spaces and physical activity, including the public space quality ${ }^{2}$. Attractive open spaces and parks that are well maintained might encourage visiting, consequently encouraging physical activity 8,9,10,11. The number and kind of available facilities and amenities could also be significant 10 , and a previous study showed that the presence of more facilities was positively associated with the probability of visiting public spaces and engaging in physical activity there ${ }^{12}$. Safety is also a significant aspect, frequently mentioned in the literature as an obstacle to the use of public spaces 8,10 .

Walkability is another feature of urban built environment that could modify the association between public spaces and physical activity, as street condition, pedestrian facilities, and road connectivity make access to public spaces more or less difficult, and they influence the time people spend walking to and from public spaces 13,14,15. Walkability might also directly affect physical activities 16,17.

Finally, sociodemographic characteristics such as gender or age are associated with public spaces use 2,18, and they could modify the association between public spaces and physical activity. In one study, the number of nearby parks was associated with park use among women and high-income participants, whereas the area of park space in the vicinity presented stronger effects on low-income participants. Specific features of the public space also influenced participants differently according to income, gender, and age 12. Public spaces might improve health equity, if they facilitate physical activity among people who cannot afford gym membershipublic spaces or equipment for home exercise or pay for private exercise classes. Therefore, the differential association between public spaces and physical activity by social stratifiers is a topic worth exploring.

Understanding the conditions under which public spaces encourage physical activity is important for policymaking in health and urban planning. Most research in this area has been conducted in high-income countries in North America, Europe, and Oceania, where public spaces tend to be large and relatively well maintained. Thus, studies from low- and middle-income countries are required 19 . Our work adds to the literature by exploring these issues in two cities in Mexico, and by using a mixed-methods design to suggest explanations for statistical results. Our objectives in this study were: (1) to assess the association of access to public spaces and physical activity; (2) to assess the modification of the association by public spaces quality, walkability, and social stratifiers; and (3) to employ qualitative data to explain the quantitative results.

\section{Methods}

\section{Design and site}

A mixed-methods triangulation study 20 was conducted in 2017-2019. The quantitative components were household survey, and evaluation of public spaces quality and walkability. The qualitative components included individual semi-structured interviews, focus groups, and non-participant observation. For this article, we employed results of all aforementioned methods, except the focus groups.

The study was conducted in Tijuana (1.6 million inhabitants) and Ciudad Juarez (1.4 million inhabitants), Mexico. The cities share a recent past of rapid industrial growth and high internal migration, and high murder and crime rates. The climate in Tijuana is semi-arid, and in Ciudad Juarez it is arid with ample variations in temperature between seasons. In both cities, municipal regulations mandate that city developments include public spaces, but they allow for public spaces to be small and keep their maintenance unregulated 21,22. 


\section{Household survey}

The primary sampling units were Basic Geographical Statistical Areas (AGEB), selected from five strata of marginalization (defined by Mexico's National Institute of Statistics and Geography - INEGI). Some blocks were selected from each AGEB, then, households were selected from each block, and one adult was selected from each household. Selection criteria for individuals were: (1) aged between 18 and 65 years old; (2) reside in the selected household; (3) having no cognitive or language impairment to understand and to answer the questionnaire; (4) agreeing to participate after signing an informed consent form. The response rate was $82 \%$ in Tijuana and $85 \%$ in Ciudad Juarez.

Physical activity in a typical week was measured with the World Health Organization's (WHO) Global Physical Activity Questionnaire (GPAQ), a 22-item instrument asking about moderate and vigorous physical activity (work, leisure time, and transport). We scored the instrument following WHO's protocol 23, obtaining MET-minutes/week. Reports $\geq 16$ hours of physical activity per day in any domain were excluded. We computed three dichotomous dependent variables: engaging in at least 600 MET-minutes/week of overall physical activity (WHO's recommendation for physical activity) 1,23 , engaging in at least $600 \mathrm{MET}$-minutes/week of leisure-time physical activity (as some authors suggest that leisure-time physical activity is more relevant for health than occupational physical activity 24,25), and engaging in at least some transport physical activity - as one of the mechanisms proposed for the association between public spaces and physical activity is that public spaces make walking more attractive 6,18 .

We considered gender, age, socioeconomic level (index of household assets and housing characteristics), years of education, and occupation as social stratifiers. The controls were perceived health (bad/fair/good/very good) and main mode of transport (private car, public transport, bicycling/walking).

\section{Geographic information system data}

We defined public space as places accessible at no cost, where sports and other recreational activities can be performed. We obtained lists of public spaces from municipality records, from databases compiled by two authors, and from Google Earth images (https://www.google.com/earth/). We obtained the number and area of public spaces in 400, 800,1,200, and 1,600 meters buffers around the blocks where survey participants resided in order to evaluate access, determining the area of all public spaces in each buffer for the participants. The distribution of the area variable was right-skewed, with a high proportion of zeroes (i.e. no public space in the buffer), so for better adjustment and easiness of interpretation we computed a three-level categorical variable: 0, 1-9,999, and $\geq 10,000$ meters of public spaces in the buffer. Categories were chosen as having some vs. none public spaces nearby could make a difference, and previous studies suggest public spaces must have a minimum size to encourage physical activity, with 1 ha as a commonly suggested cutoff 6,26. All geographic information system (GIS) data were managed with Arcmap 10.4 and Arcgis 10.5.1 (https://www.esri.com/en-us/home).

We computed three variables with data from INEGI in order to assess walkability at the AGEB level: urban complexity, pedestrian facilities and slope. For urban complexity, we used Shannon's index, higher values of which indicate more diverse destinations (e.g. shops, schools, etc.) in the AGEB 27. The pedestrian facilities index was computed as the average number of elements such as sidewalks, streetlights, etc. estimated over all blockfronts in the AGEB. Slope was a relevant variable, as Tijuana's steep topography makes walking difficult in some areas, and we measured it at the AGEB level using topographic data from INEGI. More detail about the measurements of walkability in the EPAF (Espacios Públicos y Actividad Física en Ciudades del Norte de México) project can be found in Tena Gutierrez 28 . 
We employed the Physical Activity Resources Assessment (PARA) 29, an inventory assessing three dimensions: facilities for physical activity (e.g. sports fields, playground), amenities (e.g. benches, drinking fountains), and incivilities (e.g. litter, graffiti). Each dimension was scored in two ways: a sum of the number of items present in the public space, and the average score for the items in the dimension. In the second set of scores, values range between 0 and 3. For facilities and amenities, a higher score indicates better quality, whereas for incivilities a higher score indicates more incivility.

Because of logistic limitations, in Tijuana we obtained inventories only for public spaces intersecting AGEB in the household survey (135 public spaces), and in Ciudad Juarez we stratified the AGEB by marginalization and density of public spaces and for each stratum selected at random the AGEB in which public spaces were visited (160 public spaces). We assigned to each participant the average score of public spaces intersecting or bordering the buffers around their residence block.

\section{Qualitative data}

We selected two neighborhoods in each city for maximum variability of walkability, and for being safe enough for field work and having at least one public space. Then, we conducted individual interviews ( $\mathrm{n}=48$ in Tijuana, $\mathrm{n}=30$ in Ciudad Juarez), recruiting participants by contact with local groups, personal contacts, approaching people in the public space, and by snowball sampling from interviewees. We aimed for a diversity of participants regarding age groups, gender, and physical activities practice. The interviewer asked about perceptions of the neighborhood, perceptions and use of public spaces, current and life course practices of physical activities. The interviews were carried out in the participants' households, parks, school rooms or coffee shops, and recorded and transcribed verbatim for analysis.

In the same neighborhoods, researchers visited one public space and one main street for nonparticipant observation, in three periods (morning, noon, and evening), a weekday and a weekend day, and two seasons (hot and cold). The observation guide included impressions of the site, climate, people presence, means of transport to and through the space, and people's activities.

\section{Analysis and quantitative-qualitative integration}

For quantitative analysis, we employed hierarchical (multilevel) logistic regression models, with individuals grouped into AGEB 30. We adjusted a null model to assess between-AGEB variance in physical activity, and a model of fixed effects in the individual level with access to public spaces, public spaces quality, social stratifiers, and control variables, to which we added interaction terms. None of the interactions between access to public spaces and public spaces quality, nor between access to public spaces and social stratifiers, had $\mathrm{p}<0.05$, and neither did the scores of public spaces quality; as such, we dropped them from further models. We added AGEB-level walkability variables to the model and explored the interactions between access to public spaces and walkability. We maintained walkability variables with $\mathrm{p}<0.05$ and dropped the interaction terms as none presented $\mathrm{p}<0.05$. Finally, we tested whether the addition of random slopes for access improved the model, with likelihood ratio tests 31 . The models with random slopes were not significantly better than the fixed effects models, so we did not include random slopes in the final models. In all tests, we explored the effect of different indicators of access to public space (continuous and categorical variables for area of public spaces, and number of public spaces, in buffers from 400 to 1,600 meters). All results were similar, and in this article only the models with the categorical variable for $400 \mathrm{~m}$ buffer are shown, as this is an accessible distance for most users 32 . All analyses were separately carried out for each city using Stata 15.0 (https://www.stata.com).

We focused the qualitative analysis on the exploration of participants' physical activities in public spaces. We conducted thematic analysis of the interviews 33 , assigning codes, synthesizing codes into themes, and exploring the relationships between themes. We compared the themes between interviewees, and between the high- and low-walkability neighborhoods. We used qualitative data based on non-participant observation to provide context. 
For the mixed-methods analysis, we used the strategy of "following a thread", in which a question or theme from one component is followed in the other 34 . As the key quantitative result was the null association between access to public spaces and physical activity, we aimed to explain it with the results of the qualitative component.

The protocol was reviewed and approved by the Ethics Research Committee of The College of the Northern Border [El Colegio de la Frontera Norte; n. 048-100817].

\section{Results}

\section{Quantitative results}

The final sample included 3,004 individuals, grouped into 257 AGEB. The analysis sample (with a valid GPAQ) was 1,427 in Tijuana and 1,501 in Ciudad Juarez. Only 53.7\% of participants in Tijuana, and $30.1 \%$ in Ciudad Juarez, met the recommendation for physical activities, and a minority engaged in leisure time physical activity or active transport (Table 1). Out of those who engaged in leisure time physical activity, most used public spaces or streets, and most said their leisure time varied according to the weather (most increased their physical activity in the hot season). As shown by the METminutes/week for each domain, the main source of physical activity in this sample was work-related. The distribution of MET-minutes/week was right-skewed, with a high percentage of participants reporting 0 MET-minutes/week of physical activities in all domains.

Only $59.4 \%$ of participants in Tijuana, and $70.1 \%$ in Ciudad Juarez, presented a public spaces in the $400 \mathrm{~m}$ buffer (Table 2). The mean number of incivilities in public spaces in the $400 \mathrm{~m}$ buffer was higher (5.6 and 5.1 respectively, out of 10 possible) than the mean number of features ( 3.2 and 4.0 out of 13 possible) or amenities (4.8 and 4.1 out of 12 possible). The mean scores for quality of features and amenities were lower than the scores for incivilities.

Table 3 presents the results of multilevel regressions by city, for the three dependent variables, with access to public spaces in the $400 \mathrm{~m}$ buffer as the main independent variable. Access to public spaces was not associated with physical activity, except for a marginal negative association in Tijuana with leisure time physical activity. On the other hand, the pedestrian facilities index was positively associated with all three dependent variables in Tijuana, and marginally with total physical activity in Ciudad Juarez. As for the social stratifiers, lower education, older age, and individuals retired or not working were associated with less physical activity. Socioeconomic level mostly had a negative association with physical activity in Tijuana, whereas the opposite was observed in Ciudad Juarez. Using public transport (as opposed to using a private vehicle) was negatively associated with total physical activity in Tijuana, but positively associated in Ciudad Juarez, and it was positively associated with transport-related physical activity in both cities.

A significant proportion of the variance in total and transport physical activity was associated with the AGEB level in the null models (intraclass correlation coefficients, Table 3). In adjusted models, about a third of the variance in total physical activity was explained by area level unmeasured characteristics.

\section{Qualitative results}

The characteristics of interview participants appear in Table 4.

The low-walkability neighborhood in Tijuana is a housing development on top of a hill, inhabited mostly by factory workers. The area presents high crime rates and deficient public services. The streets are paved, but most have very steep slopes, making private or public vehicles the preferred form of transport, even for short distances. For safety reasons we had to minimize the number of visits, so we also recruited participants from an adjacent zone, where most streets are unpaved, without sidewalks or signs. The low-walkability neighborhood in Ciudad Juarez is in the city's outskirts, in an area with middle to high level of marginality according to INEGI. Some streets are unpaved and in others, the pavement is broken, and as mountains are nearby, there is some slope as well. There are reports of drug selling, and potential risk for researchers, limiting the field work. 
Table 1

Characteristics of participants, by city. Tijuana y Ciudad Juarez, Mexico.

\begin{tabular}{|c|c|c|}
\hline Characteristics & $\begin{array}{l}\text { Tijuana } \\
(n=1,427)\end{array}$ & $\begin{array}{l}\text { Ciudad Juarez } \\
\qquad(n=1,501)\end{array}$ \\
\hline Years of age [mean (SD)] & $36.1(12.6)$ & $39.7(13.8)$ \\
\hline Female [\%] & 54.2 & 56.6 \\
\hline Years of education [mean (SD)] & $10.2(4.2)$ & $9.0(3.4)$ \\
\hline Socioeconomic level [median, IQR)] & $0.1(-1.4-1.5)$ & $-0.5(-1.5-0.8)$ \\
\hline \multicolumn{3}{|l|}{ Occupation [\%] } \\
\hline Working & 55.6 & 62.8 \\
\hline Studying & 10.3 & 3.7 \\
\hline Homemaker & 21.9 & 23.5 \\
\hline Retired/not working for health reasons/other & 12.1 & 10.0 \\
\hline \multicolumn{3}{|l|}{ Perceived health [\%] } \\
\hline Bad/Fair & 23.3 & 12.6 \\
\hline Good & 59.6 & 72.7 \\
\hline Very good & 17.2 & 14.7 \\
\hline \multicolumn{3}{|l|}{ Main transport } \\
\hline Car & 43.6 & 62.3 \\
\hline Public transport & 47.7 & 34.2 \\
\hline Bicycle or walking & 8.6 & 3.4 \\
\hline$\geq 600$ MET-minutes/week of total physical activity [\%] & 53.7 & 30.1 \\
\hline$\geq 600 \mathrm{MET}$-minutes/week of leisure time physical activity [\%] & 20.7 & 10.9 \\
\hline At least some leisure time physical activity [\%] & 26.1 & 15.9 \\
\hline At least some transport physical activity & 30.5 & 11.3 \\
\hline MET-minutes/week of overall physical activity [median, (IQR)] & $1,080(0-5,520)$ & $0(0-1,440)$ \\
\hline MET-minutes/week of work-related physical activity [median, (IQR)] & $0(0-2,920)$ & $0(0-0)$ \\
\hline MET-minutes/week of leisure time physical activity [median, (IQR)] & $0(0-160)$ & $0(0-0)$ \\
\hline MET-minutes/week of transport-related physical activity [median, (IQR)] & $0(0-420)$ & $0(0-0)$ \\
\hline Zero MET-minutes/week of overall physical activity [\%] & 43.0 & 67.7 \\
\hline Leisure time physical activity in street or public space [\%] * & 61.9 & 68.5 \\
\hline Leisure time physical activity changes with season [\%] * & 59.8 & 70.2 \\
\hline
\end{tabular}

IQR: interquartile range; SD: standard deviation.

Note: unweighted data.

* Only among those reporting doing leisure time physical activity ( $n=373$ in Tijuana, $n=238$ in Ciudad Juarez).

Although there are a few larger public spaces in the vicinity, the public spaces within these neighborhoods were smaller than 1 ha, with scarce vegetation and ill-maintained. Both of them were closed at night, and the one in Tijuana remained closed up to 9 a.m. Observers considered these public spaces unusable in the hot season because of strong direct sunlight, an impression confirmed by interviewees. In Ciudad Juarez, during the cold season with morning temperatures as low as $3^{\circ} \mathrm{C}$, the observers were uncomfortable too. They felt unsafe in the public space in Ciudad Juarez, where they saw adults drinking alcohol and probably using other drugs during daytime. Both public spaces were empty most time. The few adults who spend time in these public spaces were mainly accompanying children, and they stood close to tree shadows, without engaging in physical activities.

"...This is an arid park, and no one is in it, I guess because of the hour (...) The playground equipment looks scorching, I don't think anybody could sit there, nor in the benches" (noon observation, hot season, Tijuana).

Meanwhile, the high-walkability neighborhood in Tijuana is a suburban, middle-class development by the sea. The high-walkability neighborhood in Ciudad Juarez is a middle-class residential area in the downtown, with easy access to malls and cinemas. In both of them streets are paved and 
Access to public space, characteristics of public space and walkability, by city. Tijuana y Ciudad Juarez, Mexico.

\begin{tabular}{|c|c|c|}
\hline & Tijuana & Ciudad Juarez \\
\hline Participants with at least one public space within 400m buffer [\%] & 59.4 & 70.1 \\
\hline Participants with at least one public space within 1,200m buffer [\%] & 97.8 & 97.2 \\
\hline Number of public space within 400 m buffer * [median, (IQR)] & $1(0-2)$ & $1(0-5)$ \\
\hline Number of public space within 1,200m buffer * [median, (IQR)] & $6(3-9)$ & $18(6-25)$ \\
\hline Public space area $\left(\mathrm{m}^{2}\right)$ within $400 \mathrm{~m}$ buffer * [median, (IQR)] & $667(0-8,504)$ & $7,470(0-18,456)$ \\
\hline Public space area $\left(\mathrm{m}^{2}\right)$ within 1,200m buffer * [median, (IQR)] & $28,267(12,674-63,117)$ & $95,662(31,144-205,624)$ \\
\hline Number of features in public space within $400 \mathrm{~m}$ buffer * [mean, (SD)] & $3.2(1.6)$ & $4.0(2.1)$ \\
\hline Mean quality of features in public space within 400 m buffer * [mean, (SD)] & $0.5(0.3)$ & $0.6(0.4)$ \\
\hline Number of amenities in public space within $400 \mathrm{~m}$ buffer * [mean, (SD)] & $4.8(1.9)$ & $4.1(2.1)$ \\
\hline Mean quality of amenities in public space within 400m buffer * [mean, (SD)] & $0.8(0.5)$ & $0.7(0.4)$ \\
\hline Number of incivilities in public space within 400m buffer * [mean, (SD)] & $5.6(2.0)$ & $5.1(1.7)$ \\
\hline Mean intensity of incivilities in public space within $400 \mathrm{~m}$ buffer * [mean, (SD)] & $1.3(0.6)$ & $1.1(0.5)$ \\
\hline Mean pedestrian facilities index ** & $0.48(0.18)$ & $0.56(0.23)$ \\
\hline Mean slope ** & $0.21(0.13)$ & $0.07(0.14)$ \\
\hline Mean score in urban complexity index ** & $0.66(0.16)$ & $0.68(0.16)$ \\
\hline
\end{tabular}

IQR: interquartile range; SD: standard deviation.

Note: unweighted data.

* Only among those reporting doing leisure time physical activity ( $\mathrm{n}=373$ in Tijuana, $\mathrm{n}=238$ in Ciudad Juarez);

** Estimated over all surveyed Basic Geographical Statistical Areas (AGEB).

have sidewalks, pedestrian crossings with stop signs, streetlights, and little-to-no slope. However, there are problems with flooding in some areas, and during the rainy season potholes appear in the pavement. Although both neighborhoods are relatively safe, the streets are not well illuminated, and in Ciudad Juarez the neighbors have put fences around some blocks, creating inaccessible areas.

In Tijuana, the observed public space has an area of 2.6ha. In contrast with public spaces in low-walkability neighborhoods, where vegetation was dry and overgrown, this one looked green, and during visits maintenance workers and sprinkler irrigation were observed. Out of the three observed public spaces, this was the only one constantly visited. During the day, people having lunch and sitting on the grass or benches, parents with children, people walking dogs, groups of adolescents in school uniforms and older adults reading were spotted. Early in the morning and around sunset, older adults practiced tai chi and others jogged, walked or stretched. The public space was also part of the route for people walking, running or biking towards the beach. The only periods it was empty were one morning when a popular football match was on TV, and in a winter evening when the sun was already down.

On the other hand, the public space in the high-walkability neighborhood in Ciudad Juarez is smaller than 1 ha. It is lined by trees and well maintained. However, like public spaces in the low-walkability neighborhoods, it was mostly empty. One young male observer remarked that in a winter evening he might have scared away a visitor:

"When I got to the park, a man about 30 years old was sitting in a bench by the basketball court (...) He was smoking and talking on his cell phone, and keeps turning his head towards me, maybe he feels unsafe with me there, and after ten minutes he left the park" (evening observation, cold season, Ciudad Juarez).

So, in contrast with the low-walkability neighborhoods, public spaces in the high-walkability ones were in better state, but even so it was only the larger one that was visited by several people and used by adults for exercise. In the streets of high-walkability neighborhoods (especially in Tijuana) it was also common to observe adults jogging, walking or bicycling for exercise. 
Table 3

Multilevel regression of the association between access to public spaces and physical activity, by city. Tijuana y Ciudad Juarez, Mexico.

\begin{tabular}{|c|c|c|c|c|c|c|}
\hline & \multicolumn{2}{|c|}{$\begin{array}{c}\geq 600 \text { MET-minutes/week of total } \\
\text { physical activity }\end{array}$} & \multicolumn{2}{|c|}{$\begin{array}{c}\geq 600 \text { MET-minutes/week of leisure } \\
\text { time physical activity }\end{array}$} & \multicolumn{2}{|c|}{$\begin{array}{l}\text { At least some transport physical } \\
\text { activity }\end{array}$} \\
\hline & Tijuana & Ciudad Juarez & Tijuana & Ciudad Juarez & Tijuana & Ciudad Juarez \\
\hline Male gender & $0.13(0.15)$ & $0.52(0.17)$ * & $0.06(0.16)$ & $0.24(0.21)$ & $0.10(0.16)$ & $0.17(0.22)$ \\
\hline Age & $-0.02(0.01) * *$ & $-0.01(0.01) * * \star$ & $-0.03(0.01) * *$ & $-0.01(0.01)$ & $-0.01(0.01)$ & $-0.02(0.01) * * *$ \\
\hline Socioeconomic level & $-0.28(0.06) * *$ & $0.16(0.07)$ *** & $-0.08(0.06)$ & $0.18(0.08) * \star \star$ & $-0.26(0.06) * \star$ & $0.15(0.09) \#$ \\
\hline $\begin{array}{l}\text { Years of education, } \\
\text { mean (SD) }\end{array}$ & $0.05(0.02) * * \star$ & $0.08(0.03)$ * & $0.03(0.02)$ & $0.14(0.03)$ ** & $0.03(0.02)$ & $0.05(0.03)$ \\
\hline \multicolumn{7}{|l|}{ Occupation } \\
\hline Working & Reference & Reference & Reference & Reference & Reference & Reference \\
\hline Studying & $-0.69(0.25)$ * & $-0.68(0.41) \#$ & $-0.37(0.26)$ & $-0.06(0.44)$ & $-0.10(0.25)$ & $-0.74(0.50)$ \\
\hline Homemaker & $-0.47(0.19) * * *$ & $0.14(0.21)$ & $-0.26(0.22)$ & $0.01(0.27)$ & $-0.23(0.20)$ & $0.15(0.28)$ \\
\hline $\begin{array}{l}\text { Retired/Not } \\
\text { working/Other }\end{array}$ & $-1.44(0.23) * *$ & $-0.79(0.30)$ * & $-0.64(0.28) * \star \star$ & $0.10(0.34)$ & $-1.28(0.26) * \star$ & $-0.03(0.36)$ \\
\hline \multicolumn{7}{|l|}{ Perceived health } \\
\hline Bad/Fair & Reference & Reference & Reference & Reference & Reference & Reference \\
\hline Good & $0.13(0.17)$ & $-0.31(0.24)$ & $0.35(0.21)$ & $0.08(0.30)$ & $0.15(0.18)$ & $-0.20(0.30)$ \\
\hline Very good & $0.68(0.26)$ * & $-0.36(0.30)$ & $0.65(0.28) * * *$ & $-0.07(0.36)$ & $0.34(0.26)$ & $0.63(0.36) \#$ \\
\hline \multicolumn{7}{|l|}{ Main transport } \\
\hline Car & Reference & Reference & Reference & Reference & Reference & Reference \\
\hline Public transport & $-0.32(0.17) \#$ & $0.57(0.18)$ * & $-0.23(0.18)$ & $0.13(0.23)$ & $0.80(0.18) * \star$ & $0.88(0.23)$ ** \\
\hline Bicycle or walking & $0.28(0.28)$ & $1.76(0.44)$ ** & $-0.41(0.36)$ & $1.57(0.39)$ ** & $1.43(0.30)$ ** & $2.95(0.40)$ ** \\
\hline \multicolumn{7}{|l|}{ Public space area (m²) } \\
\hline \multicolumn{7}{|l|}{ in $400 \mathrm{~m}$ buffer } \\
\hline 0 & Reference & Reference & Reference & Reference & Reference & Reference \\
\hline $1-9,999$ & $-0.21(0.19)$ & $0.11(0.28)$ & $-0.38(0.21)$ * & $-0.25(0.32)$ & $0.05(0.19)$ & $0.46(0.35)$ \\
\hline $10,000+$ & $-0.24(0.28)$ & $-0.02(0.31)$ & $-0.26(0.27)$ & $0.09(0.32)$ & $0.38(0.27)$ & $0.46(0.36)$ \\
\hline $\begin{array}{l}\text { Pedestrian facilities } \\
\text { index }\end{array}$ & $2.10(0.82) * * *$ & $1.35(0.75) \#$ & $1.53(0.70)$ *** & $0.67(0.66)$ & $1.79(0.79) * \star \star$ & $0.61(0.74)$ \\
\hline \multicolumn{7}{|l|}{ Variance components } \\
\hline $\operatorname{var}\left(\mathrm{u}_{\mathrm{j}}\right)$ null model & $1.64(0.33)$ & $2.53(0.50)$ & $0.73(0.20)$ & $0.94(0.30)$ & $1.42(0.31)$ & $1.56(0.42)$ \\
\hline ICC null model & $0.33(0.04)$ & $0.43(0.05)$ & 0.18 & 0.22 & $0.30(0.05)$ & $32(0.06)$ \\
\hline $\operatorname{var}\left(\mathrm{u}_{\mathrm{j}}\right)$ final model & $1.65(0.34)$ & $2.03(0.44)$ & $0.82(0.23)$ & $0.41(0.22)$ & $1.42(0.33)$ & $0.87(0.32)$ \\
\hline ICC final model & $0.33(0.05)$ & $0.38(0.05)$ & $0.20(0.05)$ & $0.11(0.05)$ & $0.30(0.05)$ & $0.21(0.06)$ \\
\hline
\end{tabular}

ICC: intraclass correlation coefficient.

Note: unweighted data. Tijuana $n=1,422$, Ciudad Juarez $n=1,304$. Adjusted for all variables that appear on table. Table shows coefficient (standard error) unless otherwise indicated.

$* \mathrm{p}<0.01$

$* * p<0.001$;

$* * \star p<0.05$

$\# \mathrm{p}<0.10$

When asked if they visited the local public space for physical activities, all interviewees in low-walkability neighborhoods said they did not, because parks were littered, had no shadow, and there were no facilities for adult exercise. Some said the only time they had for exercise was at night after work, when they were too tired and public spaces and streets were unsafe. Furthermore, the two observed public spaces were closed at what would be peak times for adult exercising (early morning and evening). In the hilltop neighborhood in Tijuana, the steep slope was also mentioned as a disincentive. 
Characteristics of interview participants, by neighborhood and city. Mexico, 2017-2019.

\begin{tabular}{|c|c|c|c|c|c|}
\hline & \multicolumn{3}{|c|}{ Tijuana } & \multicolumn{2}{|c|}{ Ciudad Juarez } \\
\hline & High-walkability & Low-walkability 1 & Low-walkability 2 & High-walkability & Low-walkability \\
\hline Female [n] & 16 & 6 & 5 & 8 & 7 \\
\hline Male $[\mathrm{n}]$ & 13 & 7 & 1 & 7 & 8 \\
\hline Years of education [range] & $9-18$ & $0-16$ & $<6-16$ & $12-16$ & $0-16$ \\
\hline Years of age [range] & $18-77$ & $27-51$ & $22-47$ & $20-69$ & $18-64$ \\
\hline
\end{tabular}

Participants in the high-walkability neighborhoods similarly described some local public spaces as unattractive because they lack maintenance, but they said others were reasonably well maintained. They also mentioned safety concerns after nightfall. Some participants in Tijuana used the local public spaces for either walking, running, training with the exercise equipment, practicing parkour or walking their dogs. In Ciudad Juarez, participants in the high-walkability neighborhood said that exercising or walking in the open during the day was not an option because of the heat, whereas in the cooler evening hours safety was a barrier.

The inadequacy of local public spaces for adult leisure-time physical activity was mentioned in all neighborhoods, and the theme of public spaces being "for children" or "unequipped" emerged in many interviews.

"[Local public spaces] are for swings... they are for, like for mothers with children to go" (female participant, Tijuana).

Others said that public spaces were too small, so it would be boring to walk or run around them. The following quote has a description that was applied even to the larger public spaces in the high-walkability neighborhood in Tijuana:

"We started going together [with other women] to walk in that park. But no, I mean... no! You get dizzy with just going round-and-round" (female participant, Tijuana).

Some participants mentioned that they might use a public spaces for physical activity if it had enough fitness equipment (preferably in a closed space according to some) or fitness classes. Interviewees in the Tijuana high-walkability neighborhood coincided in saying that the only relatively adequate public spaces was one close-by, with an area of over 50ha, that has baseball and football courts, outdoor gym, trails, and a paved space where Zumba lessons are given in the mornings.

Considering the aspects aforementioned, interviewees who exercised preferred to do so in gyms, at home, or in larger public spaces away from their neighborhood (most of them farther than the $1,600 \mathrm{~m}$ buffer studied in the quantitative component of our project). In Ciudad Juarez, some participants went to larger public spaces somewhere else in the city for running, and interviewees in the high-walkability neighborhood in Tijuana visited parks, hiking or biking trails across the border in the United States.

“...Exercise is my hobby, but I do it in the gym. That daily hour or hour-and-a-half that I can use I rather use it exercising in a place with more people or with air conditioning, I don't fancy running around in this heat in one of the parks" (male participant, Ciudad Juarez).

Participants also favored larger, far away public spaces for family outings, including the beach in Tijuana, which interviewees in the low-walkability neighborhoods visited even if it meant a long drive or bus ride. Interviewees in the high-walkability neighborhood in Ciudad Juarez mentioned shopping malls as a leisure time destination:

"I like going to malls, to eat, to the movies. What I like is that they have air conditioning, and they are also safe. You can be in a mall at night, but you can't be at night in a park" (male interviewee, Ciudad Juarez).

On the other hand, echoing findings from the quantitative survey, some interviewees mentioned that their physical activities change according to the season. Most of them reported less activity during the colder months, when they preferred to stay at home. 
"In the hot season is like... I like [exercising then], because you sweat a lot [laughs] ...no, but I do like [exercising] in the hot season, I think it helps me to stay active, because the heat sort of puts you down, you feel like 'I'm sooo tired,' so I like to exercise to feel a little bit more active and not letting myself go, like getting old [laughs]. Yes". "And in the cold season doing exercise is like, mmm... I do some gymnastics, but not a lot, I prefer to cuddle [laughs], to do nothing [laughs]" (female interviewee, Ciudad Juarez).

As for the relationship between walkability and physical activities, most participants reported that they did not walk around much, either for exercise, leisure or errands. In the low-walkability neighborhood in Tijuana, reasons included litter, foul odors from uncollected garbage, and steep slopes. In both cities and both types of neighborhoods, cold and hot weather, dog waste, unpaved streets, broken pavement, and safety concerns were also mentioned. Only in the high-walkability neighborhood in Tijuana some participants purposefully walked instead of driving for local errands. Interviewees were also more likely to use the streets for biking or running and employ active transport within the neighborhood in the Tijuana's high-walkability neighborhood. The observed public spaces and the adjacent beach in this city compose an area of almost $120,000 \mathrm{~m}^{2}$, interrupted only by one minor street and the high tide, and while most local interviewees said the beach and its promenade were covered in garbage and the ocean smelled of drain discharge, they also mentioned it as a place for running, walking or visiting.

\section{Mixed-methods integration}

The qualitative data shed light on the reasons behind not visiting public spaces. Absence of greenery and shadow, low appeal, and safety concerns, were all themes raised by interviewees. They perceived local public spaces as "just for children", an expression that combined size (too small to run or walk in) and lack of adult exercising equipment. Interviewees who were more physically active in their leisure time either went to larger public spaces in other parts of the city or across the international border or got into gyms. Those who wanted to walk or be out in the open also went out of the neighborhood. Observations confirmed that only the larger public spaces in the high-walkability neighborhood in Tijuana were used by adults for activities including physical activity.

In summary, the quantitative null association could be explained by local public spaces not having the characteristics that would promote adult physical activity. Therefore, leisure time physical activity was performed or not, regardless of the presence of a near public space.

\section{Discussion and conclusions}

Contrary to our expectation, we found no quantitative association between access to public spaces and physical activities, whereas walkability was associated with the latter. Although this result is counterintuitive, it is not uncommon. A review 35 concluded that walkability was associated with physical activity in adults, while results for access to public spaces were mixed, and another found "convincing" evidence for an association between walkability and total physical activity, while the evidence for access to parks and other recreational facilities was only "possible" 36 . Studies conducted in Brazil have likewise found null 37,38 or mixed 39 results, and studies in Mexico reported null and inverse associations 5,7 .

Our qualitative results provide insight into why public spaces do not affect physical activity. According to them, small size and lack of adult-specific pieces of equipment and facilities, lack of maintenance, vegetation and shade, and safety concerns, made public spaces unattractive. The significance of shade 8 and other elements that make public spaces attractive $9,10,11$, as well as safety $5,8,10,40$ have been reported before. This study adds to the literature by showing that adults perceive public spaces that are small or lack the relevant equipment as unfit for adult exercise, a finding supported by previous study, according to which installing outdoor gyms might increase physical activities in parks 41 .

Another reason for the observed null quantitative association, might be that in our sample most physical activity was work-related, a domain over which access to public spaces would have little effect. Furthermore, the effect of access to public spaces and walkability could be context-dependent 5 . 
Studies in high-income countries generally assess larger, better equipped public spaces than the ones in our study. Results from Latin America show that positive associations between public spaces and physical activity can be explained by other area-level variables such as social development 37 , and streets and shopping malls can be more significant than parks for physical activity in the region 42 .

Considering the significance interviewees attributed to public spaces quality, it is noteworthy that we found no quantitative interaction between quality and access. This might occur because we only completed the PARA inventory in a subset of public spaces, and therefore had less statistical power. Also, most surveyed public spaces were homogeneously low-quality, so we possibly lacked in variability in quality to detect a difference.

Public spaces could promote health equity, if they provide less favored social groups with opportunities to engage in physical activities. An interaction between socioeconomic position and access to public spaces would be an indication of such opportunity, but we found no evidence of such interaction, and neither have most studies 16 . Instead, qualitative results showed that public spaces in low-walkability neighborhoods were less attractive than the larger, better equipped public spaces in Tijuana. Similarly, a study in the United States found that parks were less used by residents in lowerincome neighborhoods because of safety concerns 43 .

Among the limitations of our study are the cross-sectional design, preventing causal inference, and a subjective measure of physical activity. The generalizability of our results is limited by context. Future studies should address these issues, employing longitudinal or quasi-experimental methods, objective measures of physical activity, and ethnographic studies. Studies in Latin American and other low- and middle-income countries are required to clarify how infrastructure, climate, and social and cultural issues affect the relationship between public space and physical activity.

If public spaces are not an attractive option for leisure time physical activity, and private facilities are used instead, access is limited by economic means, therefore, resulting in health inequity. According to our qualitative data, public spaces need to present certain characteristics to be used. One criticism of urban planning is that decisions on public spaces do not consider users' needs and preferences ${ }^{44}$, and urban development legislation in Mexico promotes inadequate public spaces 21. These issues must be considered in health and urban planning policies.

\section{Contributors}

I. Bojorquez contributed to the conceptualization, methodology, formal analysis, investigation, writing-original draft, review, and editing. M. L. Romo-Aguilar, L. Ojeda-Revah, F. Lara-Valencia, H. García, R. Díaz, and P. Aranda contributed to the conceptualization, methodology, writing, review, and editing. F. Tena contributed to the methodology, investigation, writing, review, editing.

\section{Additional informations}

ORCID: Ietza Bojorquez ( 0000-0003-1723-7269); Maria de Lourdes Romo-Aguilar (0000-0001-63802770); Lina Ojeda-Revah (0000-0001-6006-8128); Fernando Tena (0000-0001-9371-5854); Francisco Lara-Valencia (0000-0002-7686-5815); Hilda García (0000-0002-6357-4525); Rolando Díaz (00000002-4117-2197); Patricia Aranda ( 0000-00028675-3809).

\section{Acknowledgments}

To the Mexican National Council of Science and Technology for the financial support. 


\section{References}

1. Dumith SC, Hallal PC, Reis RS, Kohl 3rd HW. Worldwide prevalence of physical inactivity and its association with human development index in 76 countries. Prev Med 2011; 53:24-8.

2. Bedimo-Rung AL, Mowen AJ, Cohen DA. The significance of parks to physical activity and public health: a conceptual model. Am J Prev Med 2005; 28(2 Suppl 2):159-68.

3. Kaczynski AT, Henderson KA. Environmental correlates of physical activity: a review of evidence about parks and recreation. Leis Sci 2007; 29:315-54.

4. Schipperijn J, Cerin E, Adams MA, Reis R, Smith G, Cain K, et al. Access to parks and physical activity: an eight country comparison. Urban For Urban Green 2017; 27:253-63.

5. Salvo D, Reis RS, Stein AD, Rivera J, Martorell R, Pratt M. Characteristics of the built environment in relation to objectively measured physical activity among Mexican adults, 2011. Prev Chronic Dis 2014; 11:E147.

6. King TL, Thornton LE, Bentley RJ, Kavanagh AM. Does parkland influence walking? The relationship between area of parkland and walking trips in Melbourne, Australia. Int J Behav Nutr Phys Act 2012; 9:115.

7. Bojorquez I, Ojeda-Revah L, Diaz R. Access to public spaces and physical activity for Mexican adult women. Cad Saúde Pública 2018; 34:e00065217.

8. Costigan SA, Veitch J, Crawford D, Carver A, Timperio A. A cross-sectional investigation of the importance of park features for promoting regular physical activity in parks. Int J Environ Res Public Health 2017; 14:1335.

9. Akpinar A. How is quality of urban green spaces associated with physical activity and health? Urban For Urban Green 2016; 16:76-83.

10. McCormack GR, Rock M, Toohey AM, Hignell D. Characteristics of urban parks associated with park use and physical activity: a review of qualitative research. Health Place 2010; 16:712-26.

11. Sugiyama T, Francis J, Middleton NJ, Owen N, Giles-Corti B. Associations between recreational walking and attractiveness, size, and proximity of neighborhood open spaces. Am J Public Health 2010; 100:1752-7.

12. Kaczynski AT, Besenyi GM, Stanis SA, Koohsari MJ, Oestman KB, Bergstrom R, et al. Are park proximity and park features related to park use and park-based physical activity among adults? Variations by multiple sociodemographic characteristics. Int J Behav Nutr Phys Act 2014; 11:146.

13. Koohsari MJ, Kaczynski AT, Giles-Corti B, Karakiewicz JA. Effects of access to public open spaces on walking: is proximity enough? Landsc Urban Plan 2013; 117:92-9.

14. Kaczynski AT, Koohsari MJ, Stanis SA, Bergstrom R, Sugiyama T. Association of street connectivity and road traffic speed with park usage and park-based physical activity. Am J Health Promot 2014; 28:197-203.
15. Sugiyama T, Paquet C, Howard NJ, Coffee NT, Taylor AW, Adams RJ, et al. Public open spaces and walking for recreation: moderation by attributes of pedestrian environments. Prev Med 2014; 62:25-9.

16. Smith M, Hosking J, Woodward A, Witten K, MacMillan A, Field A, et al. Systematic literature review of built environment effects on physical activity and active transport: an update and new findings on health equity. Int J Behav Nutr Phys Act 2017; 14:158.

17. McCormack GR, Shiell A. In search of causality: a systematic review of the relationship between the built environment and physical activity among adults. Int $\mathrm{J}$ Behav Nutr Phys Act 2011; 8:125.

18. Koohsari MJ, Mavoa S, Villanueva K, Sugiyama T, Badland H, Kaczynski AT, et al. Public open space, physical activity, urban design and public health: concepts, methods and research agenda. Health Place 2015; 33:75-82.

19. Kabisch N, Qureshi S, Haase D. Human-environment interactions in urban green spaces: a systematic review of contemporary issues and prospects for future research. Environ Impact Assess Rev 2015; 50:25-34.

20. Creswell JW, Plano-Clark V. Designing and conducting mixed methods research. Thousand Oaks: SAGE; 2007.

21. Ojeda-Revah L, Bojorquez I, Osuna JC. How the legal framework for urban parks design affects user satisfaction in a Latin American city. Cities 2017; 69:12-9.

22. Romo-Aguilar MDL. Áreas verdes y justicia social. Crisol: Fusión de Ideas 2008; 1:9-24.

23. World Health Organization. Global Physical Activity Questionnaire (GPAQ): analysis guide. Geneva: World Health Organization; n.d.

24. Coenen P, Huysmans MA, Holtermann A, Krause N, van Mechelen W, Straker LM, et al. Do highly physically active workers die early? A systematic review with meta-analysis of data from 193,696 participants. Br J Sports Med 2018; 52:1320-6.

25. Holtermann A, Hansen JV, Burr H, Sogaard K, Sjogaard G. The health paradox of occupational and leisure-time physical activity. Br J Sports Med 2012; 46:291-5.

26. van den Bosch MA, Mudu P, Uscila V, Barrdahl M, Kulinkina A, Staatsen B, et al. Development of an urban green space indicator and the public health rationale. Scand J Public Health 2016; 44:159-67.

27. Talavera-Garcia R, Soria-Lara JA. Q-PLOS, developing an alternative walking index. A method based on urban design quality. Cities 2015; 45:7-17.

28. Tena Gutierrez F. Relación entre caminabilidad física y percibida en Tijuana, México [Masters Thesis]. Tijuana: El Colegio de la Frontera Norte; 2018. 
29. Lee RE, Booth KM, Reese-Smith JY, Regan G, Howard HH. The Physical Activity Resource Assessment (PARA) instrument: evaluating features, amenities and incivilities of physical activity resources in urban neighborhoods. Int J Behav Nutr Phys Act 2005; 2:13.

30. Merlo J, Wagner P, Ghith N, Leckie G. An original stepwise multilevel logistic regression analysis of discriminatory accuracy: the case of neighbourhoods and health. PLoS One 2016; 11:e0153778.

31. LaHuis DM, Ferguson MW. The accuracy of significance tests for slope variance components in multilevel random coefficient models. Organ Res Methods 2009; 12:418-35.

32. Reyes S, Figueroa IM. Distribución, superficie y accesibilidad de las áreas verdes en Santiago de Chile. EURE 2010; 36:89-110.

33. Braun V, Clarke V. Using thematic analysis in psychology. Qual Res Psychol 2006; 3:77-101.

34. Moran-Ellis J, Alexander VD, Cronin A, Dickinson M, Fielding J, Sleney J, et al. Triangulation and integration: processes, claims and implications. Qual Res 2006; 61:45-59.

35. Carlin A, Perchoux C, Puggina A, Aleksovska $\mathrm{K}$, Buck C, Burns C, et al. A life course examination of the physical environmental determinants of physical activity behaviour: a "Determinants of Diet and Physical Activity" (DEDIPAC) umbrella systematic literature review. PLoS One 2017; 12:e0182083.

36. Van Holle V, Deforche B, Van Cauwenberg J, Goubert L, Maes L, Van de Weghe N, et al. Relationship between the physical environment and different domains of physical activity in European adults: a systematic review. BMC Public Health 2012; 12:807.

37. Boclin K, Faerstein E, Leon AC. Neighborhood contextual characteristics and leisure-time physical activity: Pro-Saude Study. Rev Saúde Pública 2014; 48:249-57.
38. Gomes CS, Matozinhos FP, Mendes LL, Pessoa MC, Velasquez-Melendez G. Physical and social environment are associated to leisure time physical activity in adults of a Brazilian city: a cross-sectional study. PLoS One 2016; 11:e0150017.

39. Hino AAF, Rech CR, Gonçalves PB, Reis RS. Acessibilidade a espaços públicos de lazer e atividade física em adultos de Curitiba, Paraná, Brasil. Cad Saúde Pública 2019; 35:e00020719.

40. García-Pérez H, Lara-Valencia F. Equidad en la provisión de espacios públicos abiertos: accesibilidad, percepción y uso entre mujeres de Hermosillo, Sonora. Sociedad y Ambiente 2016; 4:28-56.

41. Cohen DA, Marsh T, Williamson S, Golinelli $\mathrm{D}$, McKenzie TL. Impact and cost-effectiveness of family Fitness Zones: a natural experiment in urban public parks. Health Place 2012; 18:39-45.

42. Salvo D, Sarmiento OL, Reis RS, Hino AAF, Bolivar MA, Lemoine PD, et al. Where Latin Americans are physically active, and why does it matter? Findings from the IPEN-adult study in Bogota, Colombia; Cuernavaca, Mexico; and Curitiba, Brazil. Prev Med 2017; 103S:S27-33.

43. Cohen DA, Han B, Derose KP, Williamson S, Marsh T, Rudick J, et al. Neighborhood poverty, park use, and park-based physical activity in a Southern California city. Soc Sci Med 2012; 75:2317-25.

44. Byrne J, Sipe N. Green and open space planning for urban consolidation: a review of literature and best practice. Brisbane: Griffith University; 2010. 


\section{Resumen}

Los espacios públicos podrían promover la equidad en salud, proporcionando un lugar para que todas las personas practiquen actividades fisicas. Mientras que la mayoría de los estudios muestran una asociación positiva entre espacios públicos y actividades fisicas, existen todavía resultados mixtos, especialmente en países de ingresos medios y bajos. Los objetivos de estos métodos combinados fueron: (i) evaluar la asociación cuantitativa entre el acceso a espacios públicos y actividades físicas; (ii) evaluar la modificación de la asociación por la calidad de los espacios públicos, nivel de transitabilidad del área y estratificadores sociales; (iii) explicar resultados cuantitativos usando datos cualitativos. Los datos cuantitativos se obtuvieron a través de una encuesta por hogares en dos ciudades mejicanas de clima árido en 2017-2018. La actividad física se midió mediante el Cuestionario Mundial sobre Actividad Física. El acceso a los espacios públicos se midió con áreas de influencia centradas en encuestas por bloques, la transitabilidad según indicadores de nivel del área, y la calidad de los espacios públicos con la Physical Activity Resources Assessment [Evaluación de Recursos de Actividad Física]. Los datos cualitativos se obtuvieron a través de entrevistas semiestructuradas y observación del barrio. No hallamos ninguna asociación cuantitativa entre el acceso a los espacios públicos y actividades físicas, ni tampoco interacciones entre el acceso a espacios públicos y otras variables. La transitabilidad estuvo positivamente asociada con actividades físicas. El análisis cualitativo mostró que los espacios públicos locales eran raramente usados por adultos, porque los percibian como pequeños, faltos de equipamiento, poco atractivos e inseguros. Los resultados clarificaron la relación entre espacios públicos y actividades físicas, y resaltaban las mejoras en el diseño y el mantenimiento de los espacios públicos que se necesitan para lograr beneficios potenciales en la salud de la población.

Actividad Motora; Ejercicio Físico; Entorno

Construido; Parques Recreativos

\section{Resumo}

Os espaços públicos podem promover a equidade na saúde, ao prover um lugar para todas as pessoas praticarem atividades físicas. A maioria dos estudos mostra uma associação positiva entre espaços públicos e atividade física, mas ainda há resultados conflitantes, principalmente em paises de renda baixa e média. Os objetivos deste estudo de métodos mistos foram: (i) avaliar a associação quantitativa entre o acesso aos espaços públicos e atividade física; (ii) avaliar a modificação da associação pela qualidade dos espaços públicos, a caminhabilidade das áreas e fatores de estratificação social; e (iii) explicar os resultados quantitativos com base nos dados qualitativos. Os dados quantitativos foram obtidos com um inquérito domiciliar em duas cidades do semiárido mexicano em 2017-2018. A atividade física foi medida com $o$ Questionário Global de Atividade Física. Os autores mediram o acesso aos espaços públicos com buffers centrados nos quarteirões do inquérito, a caminhabilidade com indicadores em nivel de área e a qualidade dos espaços públicos com a Physical Activity Resources Assessment [Avaliação de Recursos de Atividade Física]. Os dados qualitativos foram obtidos com entrevistas semiestruturadas e observação dos bairros. Não foi encontrada associação quantitativa entre acesso aos espaços públicos e atividade física, ou interações entre o acesso aos espaços públicos e outras variáveis. A caminhabilidade mostrou associação positiva com atividade física. A análise qualitativa mostrou que os espaços públicos locais eram usados raramente por adultos, porque eram percebidos como pequenos, sem equipamentos, pouco atraentes e inseguros. Os resultados ajudam a entender a relação entre os espaços públicos e atividade física, e destacam as melhorias no desenho e na manutenção dos espaços públicos que são necessárias para realizar os benefícios para a saúde da população.

Atividade Motora; Exercício Físico; Ambiente Construído; Parques Recreativos
Submitted on $15 / \mathrm{Feb} / 2020$

Final version resubmitted on 16/May/2020

Approved on 04/Jun/2020 